\title{
Enhancement of Insulating Refractory Properties of Selected Nigeria Fire-Clays Using Coconut Shell
}

\author{
Eugenia Obiageli Obidiegwu*, David Ehigie Esezobor, Johnson Olumuyiwa Agunsoye, \\ Ganiyu Ishola Lawal \\ Metallurgical and Materials Engineering Department, University of Lagos, Lagos, Nigeria \\ Email: "eugenia_obidi@yahoo.com, "eobidiegwu@unilag.edu.ng
}

Received 18 September 2015; accepted 8 November 2015; published 11 November 2015

Copyright (C) 2015 by authors and Scientific Research Publishing Inc.

This work is licensed under the Creative Commons Attribution International License (CC BY).

http://creativecommons.org/licenses/by/4.0/

\section{Abstract}

The use of coconut shell particulates to enhance the insulating refractory properties of Ukpor, Osiele and Kankara fireclays in Nigeria was studied in this paper. The chemical analysis of the raw materials was conducted using Atomic Absorption spectrometer. The samples used for different tests were prepared by mixing the clay, bentonite and coconut shell, of grain sizes of 212 - $600 \mu \mathrm{m}$. The prepared samples were air and oven dried for 24 hours at room temperature and at $110^{\circ} \mathrm{C}$ respectively. The samples were then fired at different temperatures in the range of $950^{\circ} \mathrm{C}$ to $1200^{\circ} \mathrm{C}$ at $50^{\circ} \mathrm{C}$ interval and at $2.5^{\circ} \mathrm{C} / \mathrm{min}$. The fired samples were investigated for their physical, insulating (thermal) and mechanical properties. Micro-structural examination was also carried out. The results indicate that clays with $25 \mathrm{wt} \%$ - $30 \mathrm{wt} \%$ coconut shell and grain sizes of 212 - 300 $\mu \mathrm{m}$ fired at $1150^{\circ} \mathrm{C}-1200^{\circ} \mathrm{C}$ possess enhanced mechanical, physical and insulating (thermal) properties. The SEM micrograph revealed the formation of mullite phase in the bricks fired at $1150^{\circ} \mathrm{C}$. Thus, high quality refractory bricks with enhanced insulating properties could be produced from Ukpor, Osiele and Kankara fire-clays blended with coconut shell particulates.

\section{Keywords}

Insulation, Mechanical Strength, Porosity, Thermal-Conductivity

\section{Introduction}

The choice of clay for the production of insulating refractory bricks depends on its physical and refractory properties. Insulating bricks are usually made from a variety of oxides, most commonly fireclay $\left(42 \% \mathrm{SiO}_{2}\right.$ and $53 \%$ $\mathrm{Al}_{2} \mathrm{O}_{3}$ ) with traces of $\mathrm{Fe}_{2} \mathrm{O}_{3}$. High iron content in clay can result to low refractoriness [1]. The insulating prop${ }^{*}$ Corresponding author.

How to cite this paper: Obidiegwu, E.O., Esezobor, D.E., Agunsoye, J.O. and Lawal, G.I. (2015) Enhancement of Insulating Refractory Properties of Selected Nigeria Fire-Clays Using Coconut Shell. Journal of Minerals and Materials Characterization and Engineering, 3, 458-468. http://dx.doi.org/10.4236/immce.2015.36048 
erty of the refractory depends on the degree of porosity. The later translates to increase in air pockets, low bulk density and low thermal conductivity. However, high degree of porosity degrades the mechanical strength of the bricks as compared to a dense refractory brick [2].

The study on development of insulating refractory ramming mass from some Nigeria refractory raw materials, using mica and calcium aluminate as pore former indicates that the refractory materials can be used for lining of melting furnace and ceramic kilns [3]. However, these pore formers are not easily available and are expensive.

The physical and refractory properties of the Nigeria Nafuta and Kankara clay deposits are within the allowable limit for fireclay refractory and these were found to be suitable for the production of refractory bricks with good shrinkage [4] [5]. The thermal conductivity of refractory clays depends on the chemical properties, mineralogical composition, silica content of the refractory and on the application temperature [6].

This paper investigates the use of coconut shell to enhance the insulating refractory properties of bricks produced from some selected Nigeria clays and coconut shell.

\section{Materials and Methods}

The raw materials used for this research are Ukpor, Osiele and Kankara clays collected from Nnewi South L.G.A of Anambra State, Abeaokuta in Ogun State, and Kankara village in Kastina State respectively. The binder bentonite was purchased from local market while the coconut shell (C.S) was collected from coconut chips producers at Ibadan, Nigeria.

\subsection{Chemical Analysis}

The chemical analysis of the as-received materials was conducted using Atomic Absorption Spectrometer (AAS) Perklin Elmer Analyst 200.

The as-received clays and coconut shell were air dried, crushed with a jaw crusher and ground in a ball mill. The pulverized materials were later classified into various sizes ranging from 212 to $600 \mu \mathrm{m}$. Various samples comprising (60 wt\% - $100 \mathrm{wt} \%$ ) clays, $5 \mathrm{wt} \%$ of bentonite and (0 - $35 \mathrm{wt} \%$ ) of coconut shell with grain sizes of 212 - $600 \mu \mathrm{m}$ were prepared using semi-dry techniques.

The samples were then fired using electric resistance furnace at temperature ranging from $950^{\circ} \mathrm{C}$ to $1200^{\circ} \mathrm{C}$ at $50^{\circ} \mathrm{C}$ interval at $2.5^{\circ} \mathrm{C} / \mathrm{min}$.

\subsection{The Physical Properties}

\subsubsection{Bulk Density}

Bulk density and apparent porosity were determined in accordance with ASTM C373-88, 2006 Standard test methods for bulk density, apparent porosity and water absorption of refractory bricks and shapes. The dried samples with weight $(D)$ were soaked in hot (boiled) water for 3 hours. Thereafter, the soaked weight $(W)$ and suspended weight in water $(S)$ were taken. "Equation (1)" was used to evaluate the bulk density of the bricks.

$$
\text { Bulk density }=\frac{D \times \rho_{w}}{W-S}
$$

where,

$D, W$ and $S$ are the dried, soaked and suspended weights of the bricks respectively, $(g)$ and $\rho_{w}$ is the density of water $\left(\mathrm{g} / \mathrm{cm}^{3}\right)$.

\subsubsection{Porosity}

The apparent porosity expressed in percentage was calculated using Equation (2).

$$
\text { Porosity }=\frac{(W-D)}{(W-S)} \times 100
$$

\subsection{The Thermal Property}

\subsubsection{Linear Shrinkage}

The shrinkage properties of the pressed samples were determined by measuring the dimension of both the green 
and indurated bricks, using a digital vernier caliper. The three sides of the bricks were measured while the average linear shrinkage was evaluated using Equation (3).

$$
\text { Total Linear Shrinkage }=\frac{\left(L_{o}-L_{1}\right)}{L_{o}} \times 100 \%
$$

where,

$L_{o}$ and $L_{1}$ are the original and final length of the green and fired samples respectively (mm).

\subsubsection{Thermal Conductivity}

The thermal conductivity of the test samples were evaluated using the expression in Equation (4) after measuring the parameters.

$$
K=\frac{2.303 M C \delta\left[\log \left(\theta_{1} / \theta_{2}\right)\right]}{A \times \tau}
$$

where,

$K$ is the thermal conductivity of the specimen, $\left(\mathrm{W} / \mathrm{m}^{\circ} \mathrm{C}\right), T_{s}$ is temperature of steam $\left({ }^{\circ} \mathrm{C}\right), T_{1}$ is initial temperature of water in conical flask $\left({ }^{\circ} \mathrm{C}\right), T_{2}$ is Final temperature of water in conical flask $\left({ }^{\circ} \mathrm{C}\right), \tau$ is Time $(s), A$ is Specimen area, $\left(\mathrm{m}^{2}\right), \mathrm{M}$ is the mass of water in conical flask $(\mathrm{kg}), C$ is specific heat capacity of water in conical flask $\left(\mathrm{J} / \mathrm{kg}^{\circ} \mathrm{C}\right), \delta$ is thickness of specimen (m), $\theta_{1}$ is $T_{s}-T_{1}$ and $\theta_{2}=T_{s}-T_{2}$.

\subsection{The Mechanical Property}

\section{Cold Crushing Strength}

The C.C.S was determined in accordance with ASTM C133-97(2008) E1, using universal testing machine (Testometric M-500-25kN). Cubic samples of $76.2 \times 76.2 \times 76.2 \mathrm{~mm}^{3}$ were placed each on the machine and the load was applied axially by turning the hand wheel until failure occurs. The Cold crushing strengths (CCS) of the samples were calculated using Equation (5).

$$
\mathrm{CCS}=\frac{\text { Maximum Load }(\mathrm{KN})}{\text { Cross Sectional Area }\left(\mathrm{m}^{2}\right)}
$$

\subsection{Microstructural Examination}

The microstructural examination of the brick was conducted using Scanning Electron Microscope (SEM) (Zeiss, model EVO10).

\section{Results and Discussion}

\subsection{Chemical Analysis}

The result of the spectro-chemical analysis of the various clay samples revealed that the major constituent in the clay are silica $(52 \%-59 \%)$ and alumina $(26 \%-30 \%)$. Thus, the fire-clay samples belong to the family of aluminosilicate (Figure 1) and are semi-acidic refractories. The silica and the alumina contents are within the range of classification given by [7]. The Coconut shell is carbonaceous in nature due to high loss on ignition (93.5 wt\%).

\subsection{Thermal Properties}

\subsubsection{Linear Shrinkage}

The variations of the linear shrinkage of the refractory bricks as a function of various processing parameters are shown in Figure 2 and Figure 3. The results show that the refractory bricks produced with Osiele clay have the highest total shrinkage (7.36\%), as against Ukpor clay (7.19\%) and Kankara clay (5.59\%). Nevertheless, these values are within the range of ASTM C356-2010 standard for clays and in conformity with the range of (2\% $10 \%)$ and $(8 \%-13 \%)$ for dense and insulating refractory bricks respectively.

The linear shrinkage increases with increase in firing temperature. This could be as a result of the bonding 

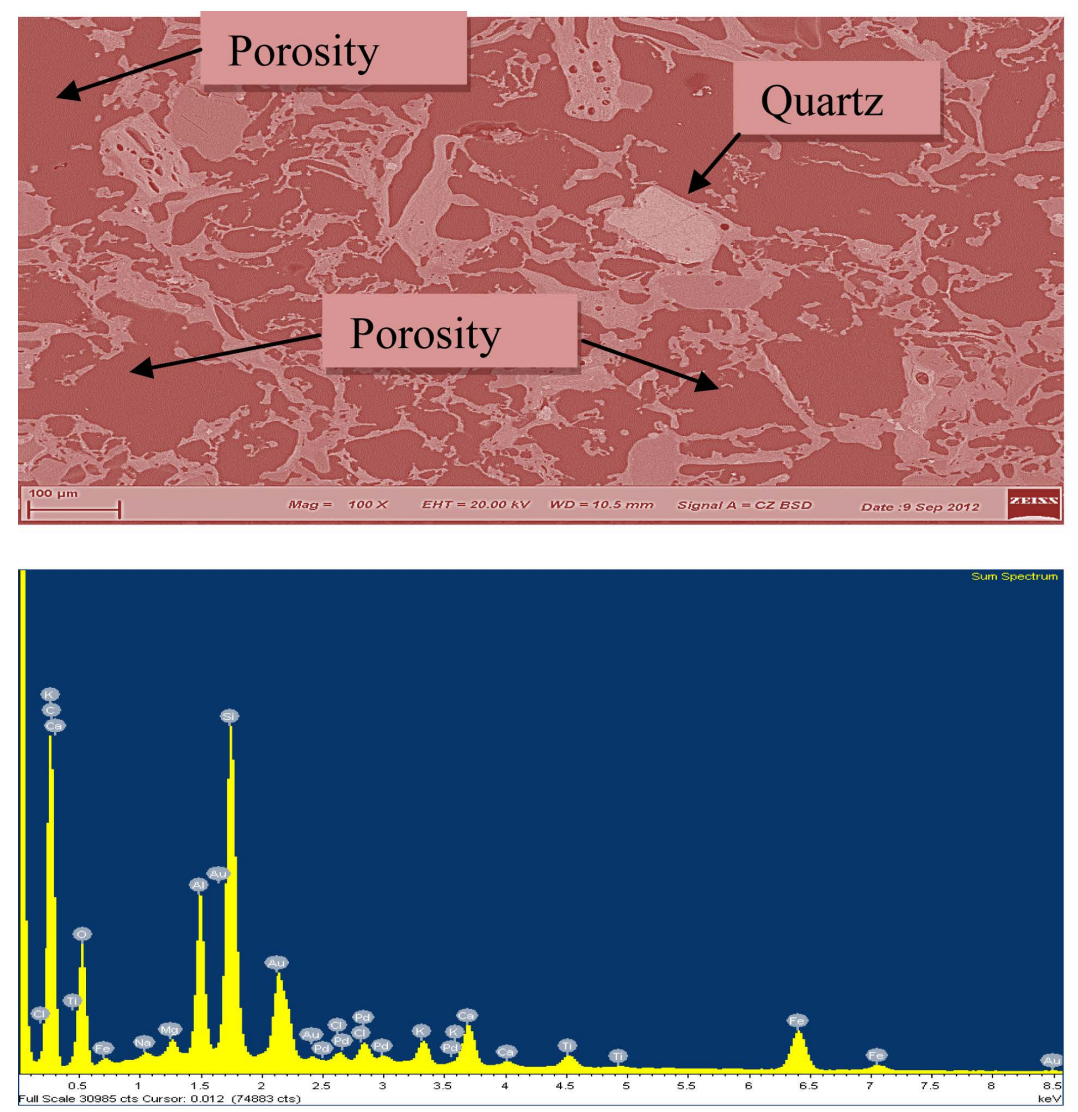

Figure 1. EDS and micrograph showing the chemical composition of the brick.

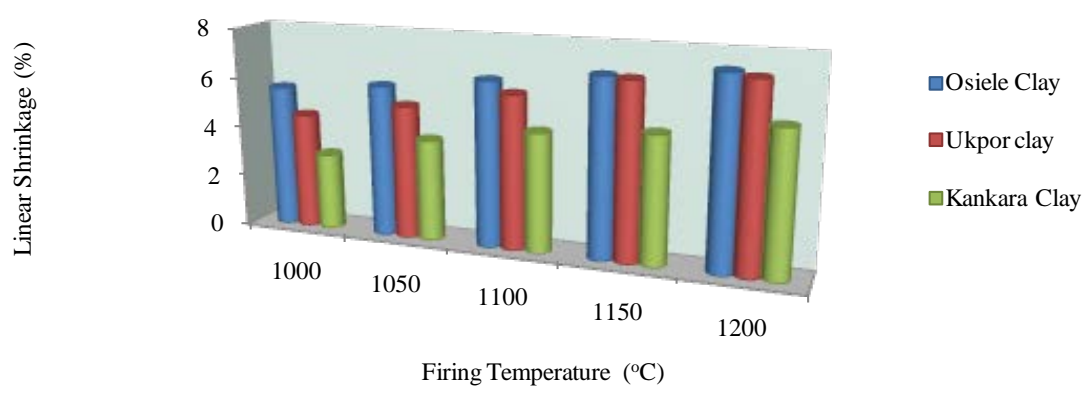

Figure 2. Variation of linear shrinkage of bricks produced from various clays at different firing temperatures.
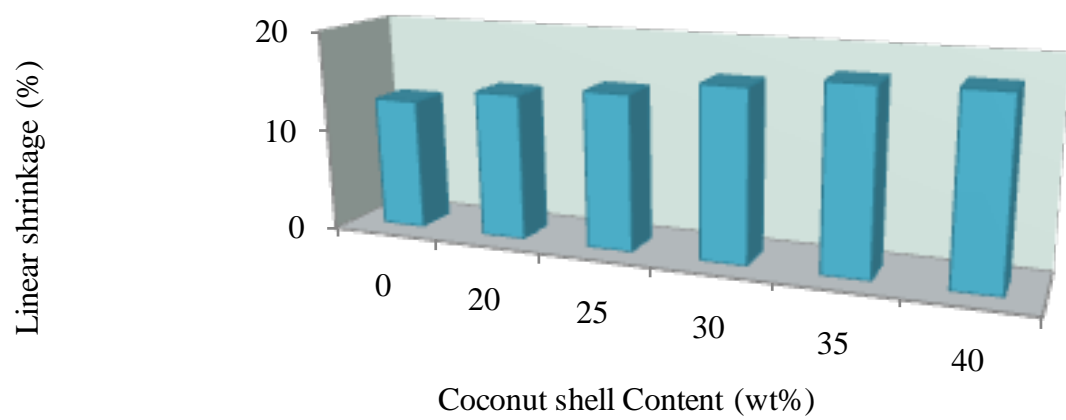

Figure 3. Effect of percentage composition of C.S on the linear shrinkage of bricks. 
between particles at high temperature with the decline in inter-particle separation [8].

Figure 3 indicates the behaveiour of linear shrinkage of the bricks at varied weight percentage of coconut shell (C.S). The linear shrinkage increases as the weight percentage of the C.S increases. This can be attributed to increase in organic (combustible) matter which burnt off during firing.

\subsubsection{Thermal Conductivity}

The results of thermal conductivity tests presented in Figure 4 showed that the thermal conductivity decreases with increase in the percentage composition of the agro-wastes. This also can be attributed to the increase in the formation of pores that hinder heat transfer from one particle to another, since heat transfer in solids is mainly by conduction. As evident in micrographs (Figure 5 and Figure 6), when there is increase in porosity, entrapped air between the particles inhibits the rate of heat transfer [9]. These empty spaces or voids (though may contain air) insulate the thermal flow hence, the reduction in thermal conductivity of the samples as the percentage C.S. (waste) admixture increases.

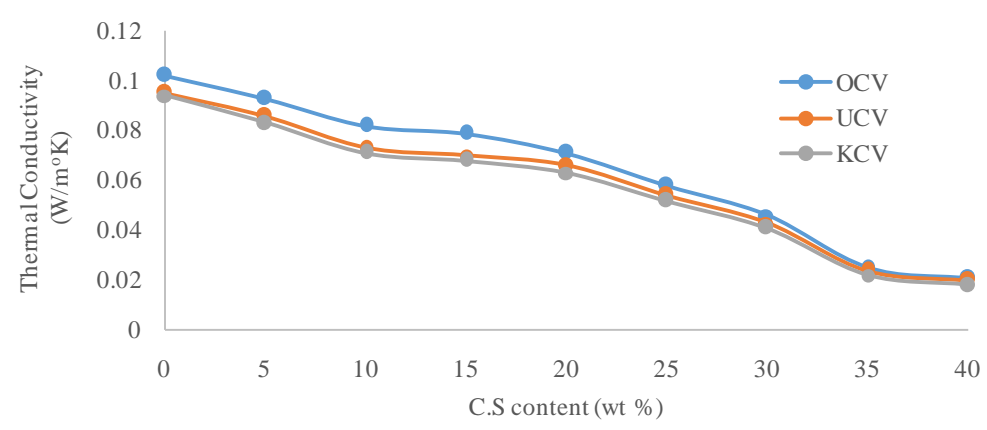

Figure 4. Variation of thermal conductivity of the bricks with C.S content.

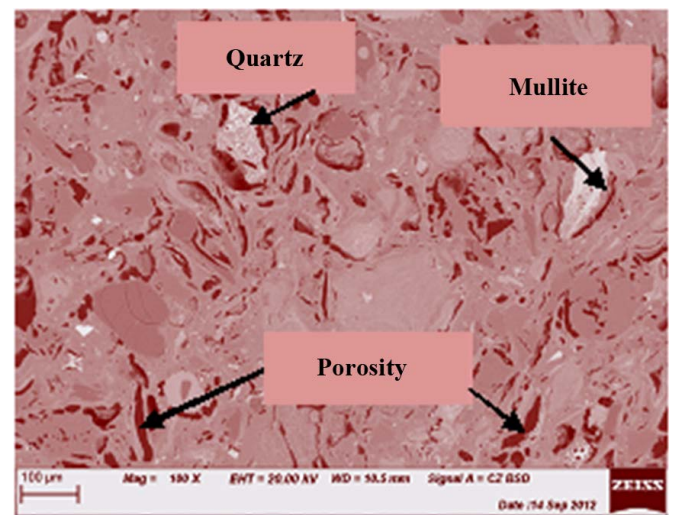

Figure 5. Brick without additive fired at $1150^{\circ} \mathrm{C}$.

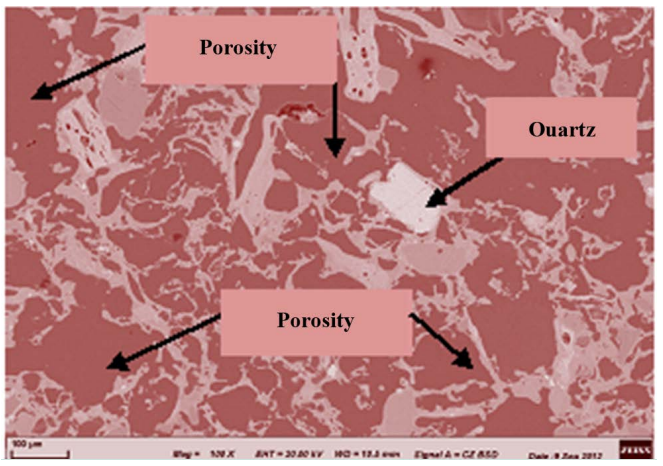

Figure 6. Brick with $40 \%$ C.S. additive fired at $1150^{\circ} \mathrm{C}$. 


\subsection{Physical Property}

\subsubsection{Bulk Density}

The bulk density is adversely affected with increase in the grain size of C.S. This is because the increase in particle size leads to low packing factor, this results in decrease of the particle content per unit volume thereby leading to decrease in the density (Figure 7).

\subsubsection{Porosity}

The porosity results obtained (Figure 8) show that as the percentage of the waste increases (from $0 \%$ to $40 \%$ ), the porosity of the samples increases (20.07\% to $88.09 \%$, for Osiele clay), (31.22\% to $89.36 \%$, for Ukpor clay) and (34.10\% to $91 \%$ for Kankara clay). This can be attributed to the levels of loss on ignition in the materials (Table 1) [10].

However, the increase in the firing or sintering temperature leads to decrease in the apparent porosity (Figure 9). The reduction of porosity is due to the vitrification process that occurred at high temperature, which results to the fusion of the particles into a coherent body with an amorphous or glassy phase. During this process, the pores tend to shrink.

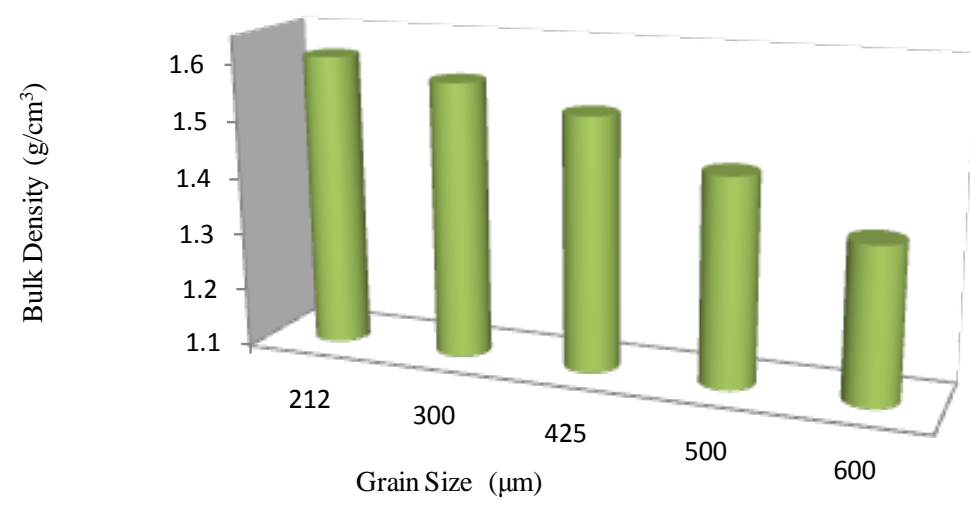

Figure 7. Variation of bulk density of firebricks with grain sizes of wastes.

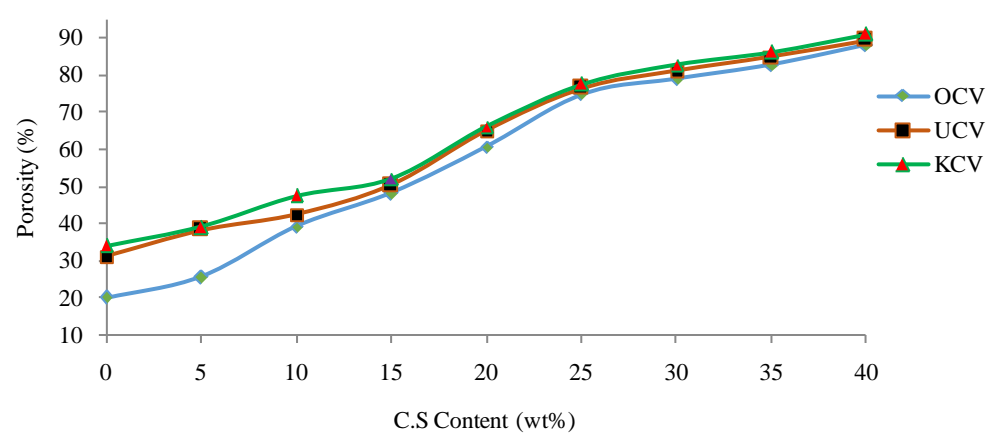

Figure 8. Variation of porosity of bricks with C.S content at $1150^{\circ} \mathrm{C}$.

Table 1. Chemical composition of the materials.

\begin{tabular}{ccccccccccccc}
\hline Materials & \multicolumn{10}{c}{ Composition, (wt \%) } \\
& $\mathbf{A l}_{2} \mathbf{O}_{3}$ & $\mathrm{SiO}_{2}$ & $\mathbf{F e}_{2} \mathbf{O}_{3}$ & $\mathbf{T i O}_{2}$ & $\mathbf{M g O}$ & $\mathbf{C a O}$ & $\mathbf{N a}_{2} \mathbf{O}$ & $\mathbf{K}_{2} \mathbf{O}$ & L.O.I & $\mathbf{M n O}$ \\
\hline Ukpor clay & 27.79 & 53.73 & 1.24 & 0.55 & 0.89 & 0.01 & 0.56 & 2.10 & 13.16 & - \\
Osiele clay & 30.31 & 51.73 & 1.46 & 0.07 & 0.31 & 0.16 & 0.62 & 2.31 & 13.06 & - \\
Kankara clay & 25.72 & 58.84 & 0.86 & 0.34 & 0.69 & 0.24 & 0.35 & 1.44 & 11.52 & - \\
Coconut shell & 1.92 & 2.46 & 0.24 & - & 0.11 & 0.15 & 0.20 & 0.13 & $\mathbf{9 3 . 4 7}$ & 0.03 \\
\hline
\end{tabular}




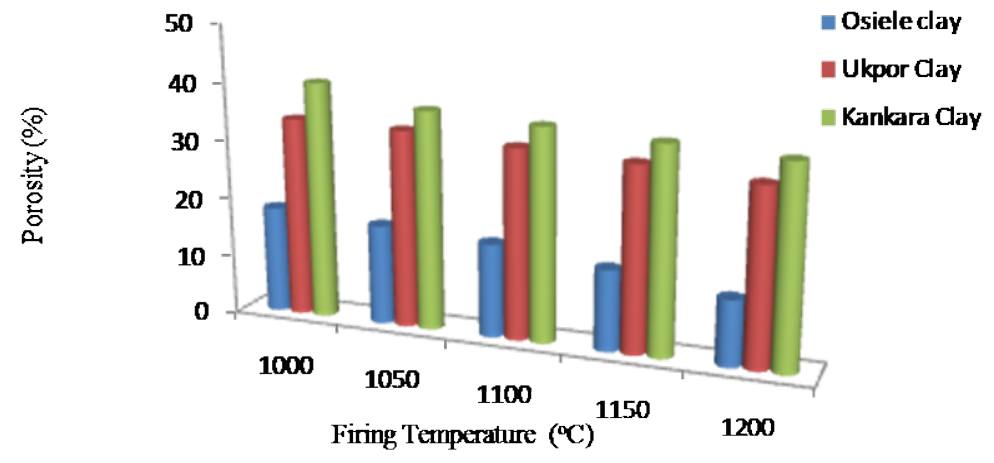

Figure 9. Variation of porosity of the brick with the firing temperature.

\subsection{Mechanical Property}

\section{Cold Crushing Strength (CCS)}

Figure 10 shows the result of variation of cold crushing strength with firing temperature. From the graph, it can be observed that there is upward swing at temperature between $1000^{\circ} \mathrm{C}$ to $1130^{\circ} \mathrm{C}$ which indicates the range of temperature at which most of the particle fuse together to form a coherent body leading to sharp increase in the CCS. At a higher temperature (above $1130^{\circ} \mathrm{C}$ ), the trend tends to reduce. This is as a result of vitrification that has taken place at a higher temperature, while forming glassy phase leading to reduction in strength of the material [11].

The CCS of the bricks produced with admixture of coconut shell (C.S) and Osiele clay (OCX), as well as Ukpor clay (UCX) are within ASTM C133-97(2008) standard of greater than $1000 \mathrm{kN} / \mathrm{m}^{3}$ for medium insulating refractory brick. The reverse is in the case for bricks with Kankara clay (KCX).

\subsection{Mineralogical Examination Result}

The Mineralogical analyses carried out through XRD and the results interpreted using International Centre for Diffraction Data (ICCD) software (Figure 4.25 to 4.29) revealed that the basic mineralogical content of the sample are Quartz $\mathrm{SiO}_{2}$ (ICCD 00-005-0490), Corundum $\mathrm{Al}_{2} \mathrm{O}_{3}$ (ICCD00-042-1468) and Mullite $2 \mathrm{Al}_{6} \mathrm{SiO}_{13}$ (ICCD01083-1881). The XRD also shows a change of clay phase when sintered from $1000^{\circ} \mathrm{C}$ to $1200^{\circ} \mathrm{C}$, (Figures 11-13). The peak of Quartz $(\alpha)$ and Corundum $(\beta)$ reduces when sintered from $1000^{\circ} \mathrm{C}$ to $1200^{\circ} \mathrm{C}$. This is due to formation of mullite Phase ( $\gamma$ ), (Johari et al., 2010). A new phase of mullite develops between temperatures of $1100^{\circ} \mathrm{C}$ to $1200^{\circ} \mathrm{C}$. The peak also appears sharp, showing a highly crystalline compound. Depending on the temperature and on the content of silica and alumina, aluminosilicate clays, upon heating, form various combinations of alumina, cristobalite, mullite, and liquid. The formation of liquid phases is important in the partial vitrification of clay-based ceramics.

\subsection{Microstructural Examination Result}

The images in Figures 14-19 revealed an increase of the volume of porosity from unfired (control) sample (Figure 10) to fired samples at various temperatures. The sample with $100 \%$ clay (OT1) sintered at $1000^{\circ} \mathrm{C}$ contains quartz and corundum having trapezoidal and oval shape respectively (Figure 15). As the temperature increases to $1150^{\circ} \mathrm{C}$, a needle like shape is observed showing the formation of a highly crystalline new compound mullite, while the quartz phase is disappearing (Figure 15, Figure 16). This can be seen from the reduction in the size of quartz.

It is also observed that while the size of porosity increases at increase in the grain sizes of agro-waste, the same porosity decreases at increase in the firing temperatures (Figures 16-19).

Note: The symbols for the brick samples are as follows; 5 stands for $20 \mathrm{wt} \%$ of coconut shell (C.S); V, X and $\mathrm{Z}$ stands for grain sizes of $212 \mu \mathrm{m}, 425 \mu \mathrm{m}$ and $600 \mu \mathrm{m}$ respectively; T1 and T4 stands for firing Temperatures of $1000^{\circ} \mathrm{C}$ and $1150^{\circ} \mathrm{C}$ respectively and O stands for Osiele clay.

\section{Conclusions}

It can be concluded from the study that Osiele, Ukpor and Kankara clays belong to aluminosilicate group. The 


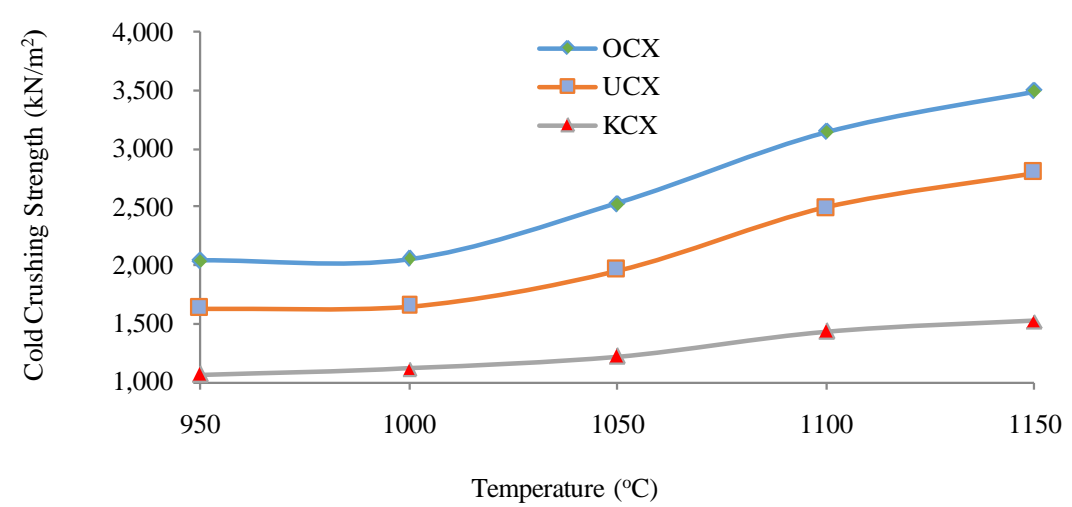

Figure 10. Variation of CCS with firing temperature.

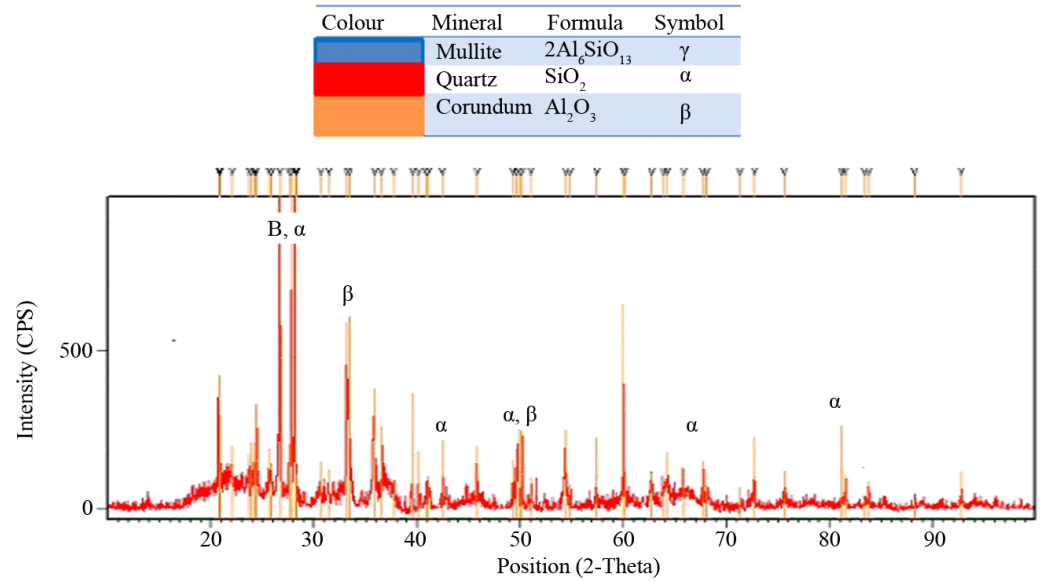

Figure 11. XRD of brick fired at $1000^{\circ} \mathrm{C}$.

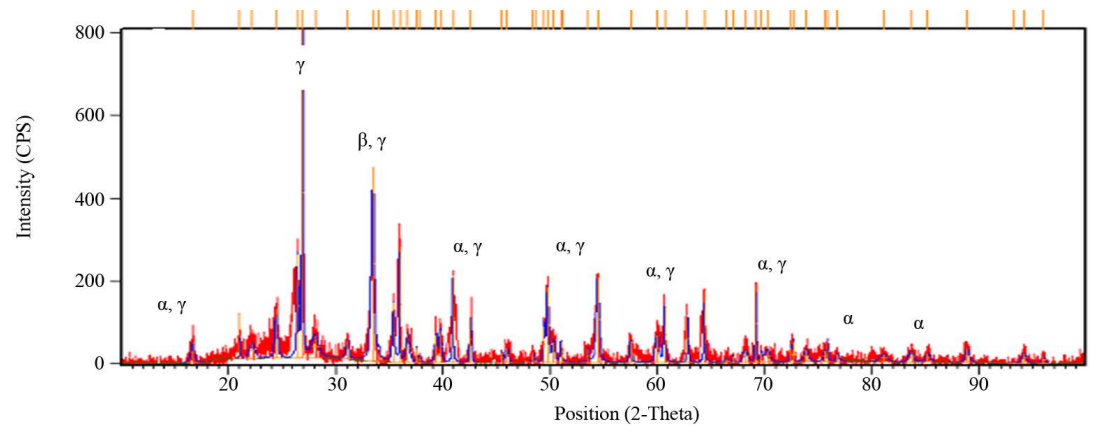

Figure 12. XRD of brick fired at $1200^{\circ} \mathrm{C}$.

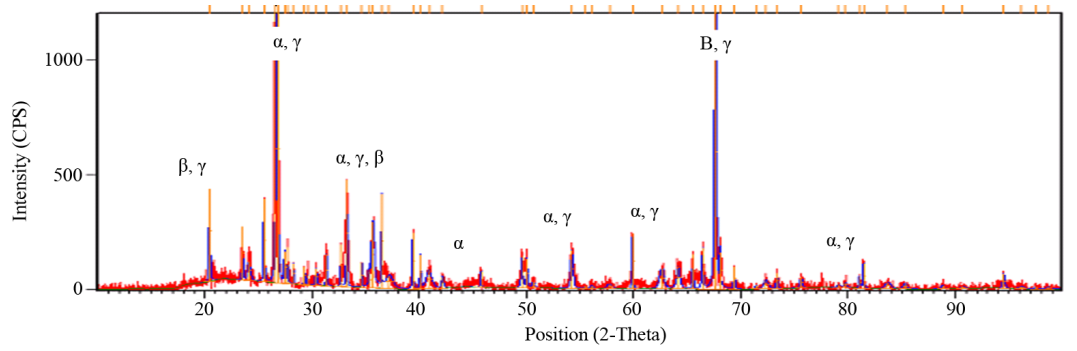

Figure 13. XRD of brick fired at $1150^{\circ} \mathrm{C}$. 


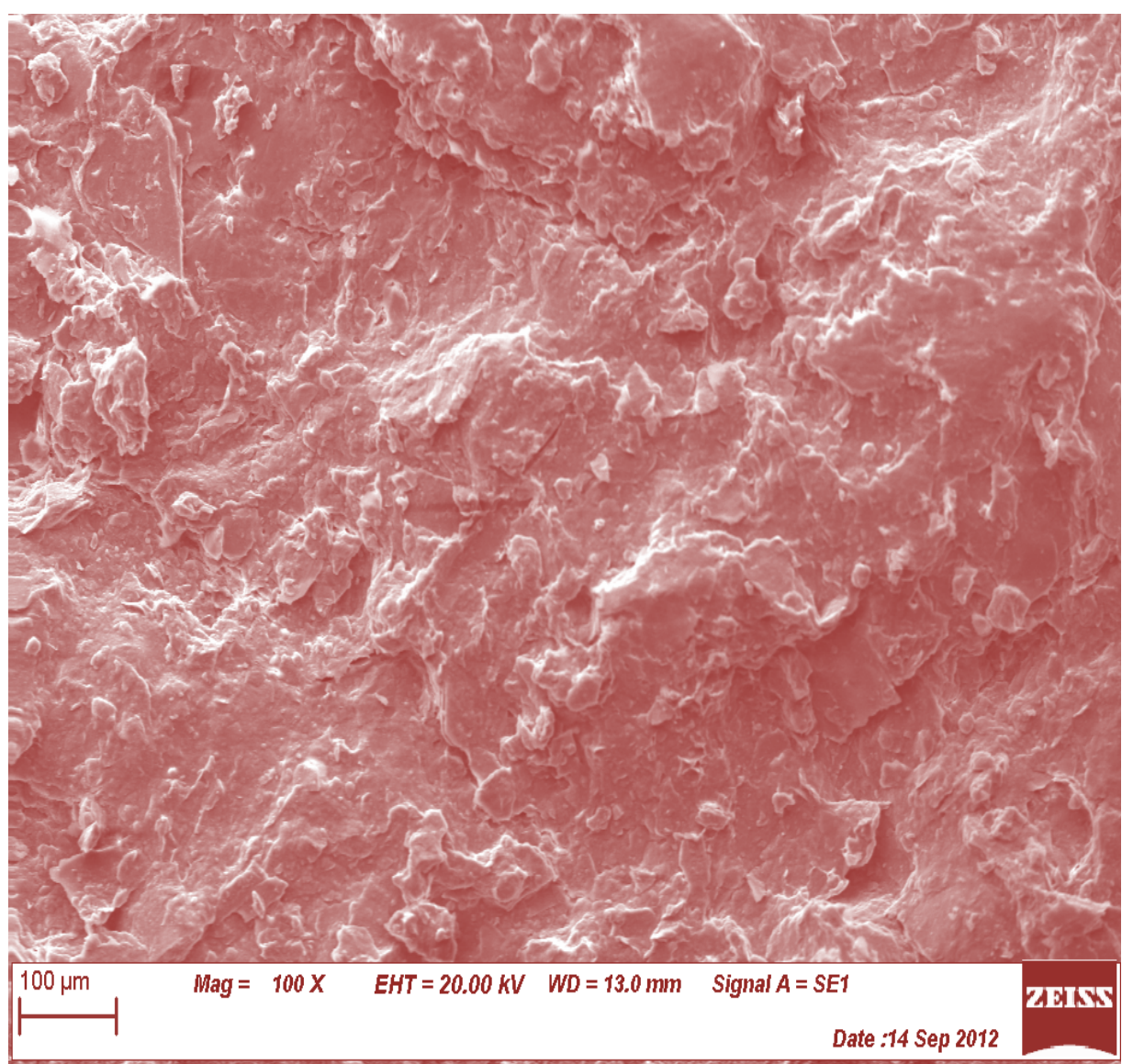

Figure 14. SEM of Unfired clay (100×).

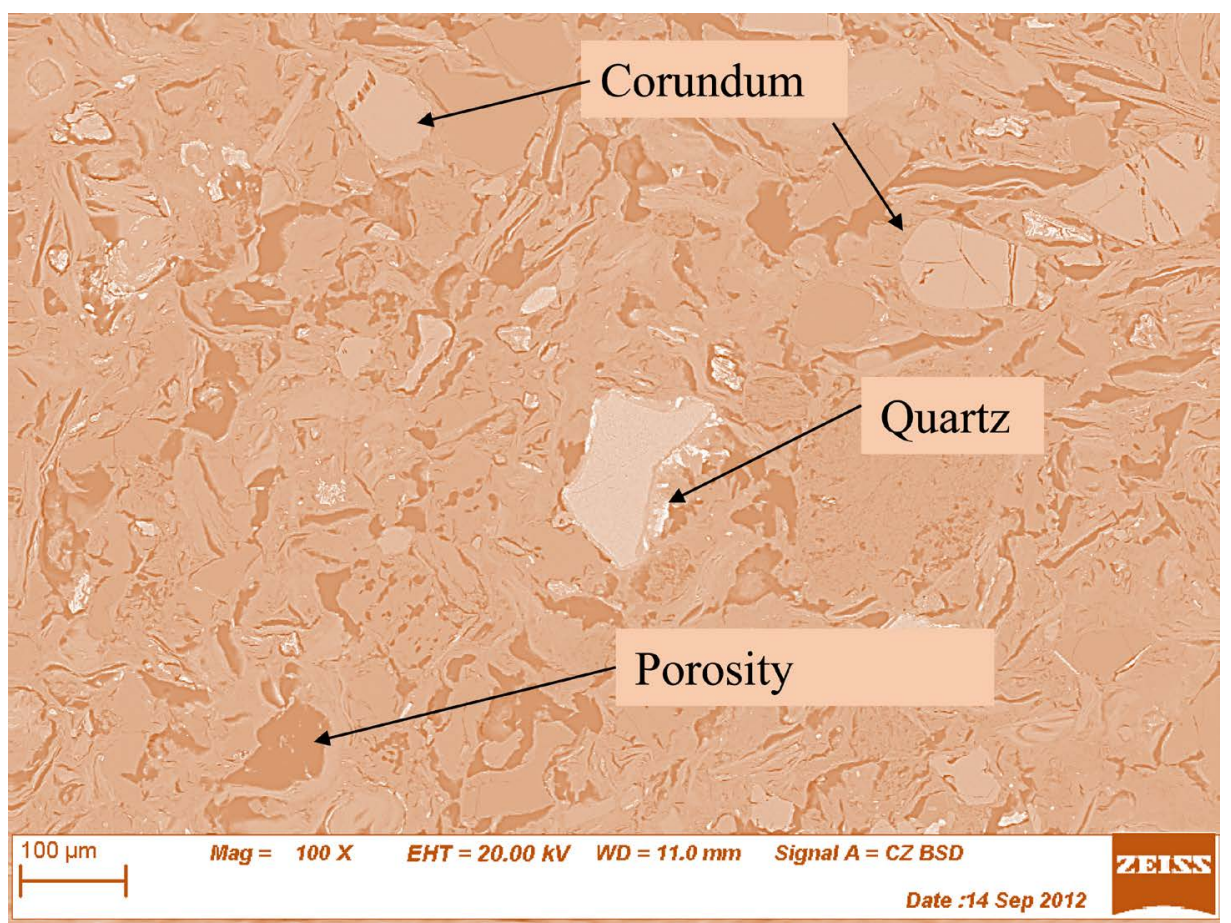

Figure 15. SEM of OTI fired at $1000^{\circ} \mathrm{C}$. 


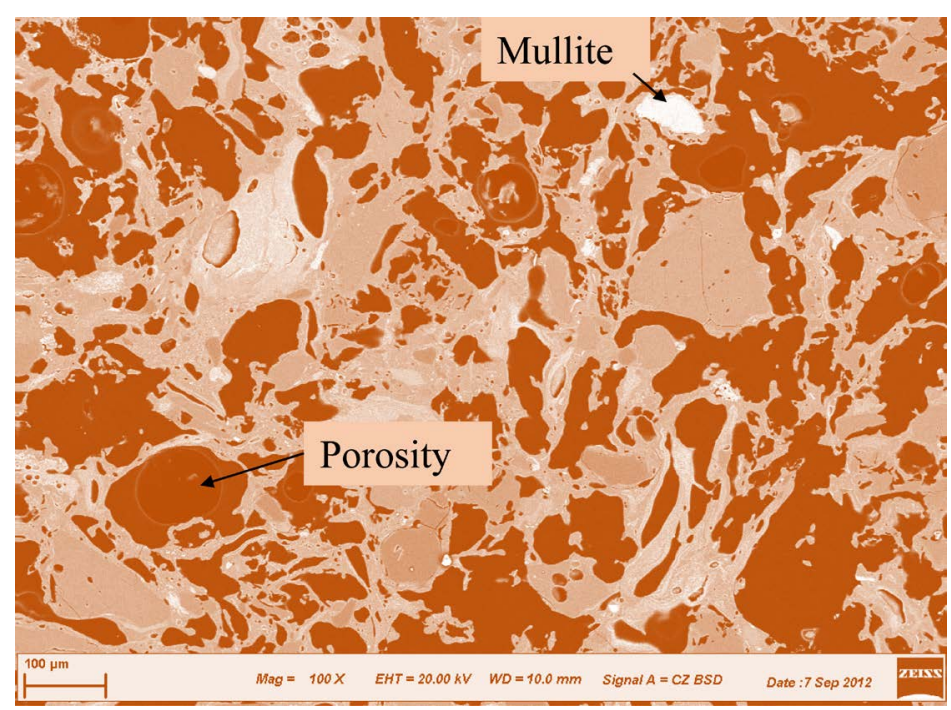

Figure 16. Sample $5 \mathrm{OCVT} 4$ at $1150^{\circ} \mathrm{C}$.

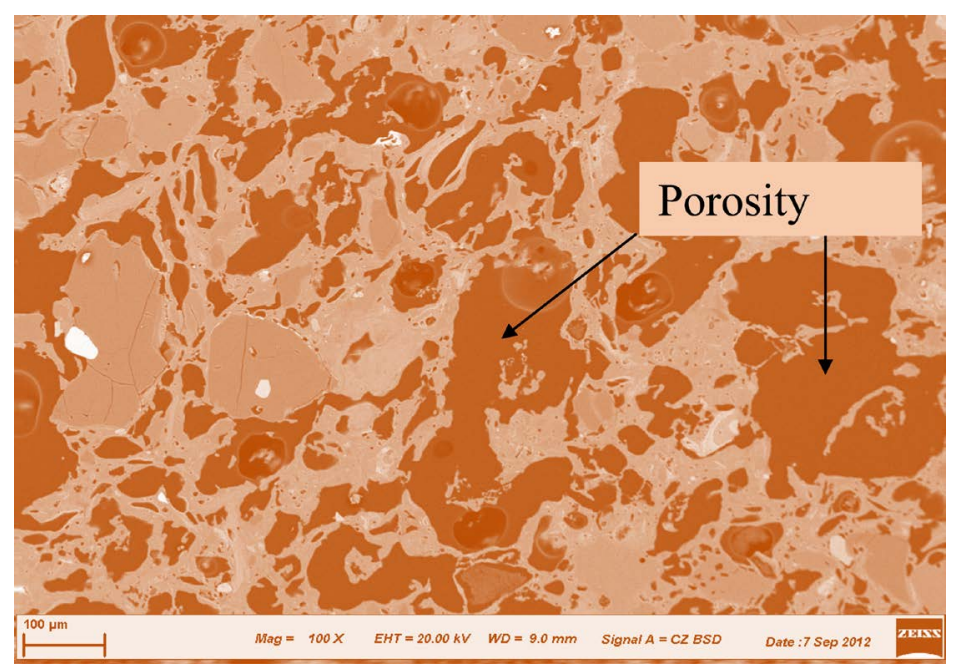

Figure 17 . Sample $5 \mathrm{OCXT} 4$ at $1150^{\circ} \mathrm{C}$.

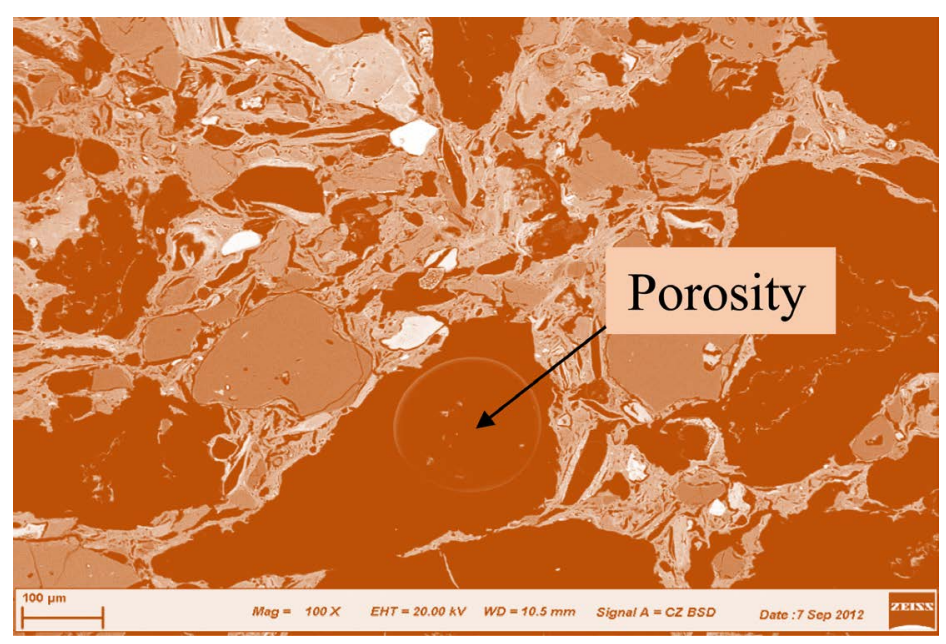

Figure 18. Sample 5OCZT1 at $1000^{\circ} \mathrm{C}$. 


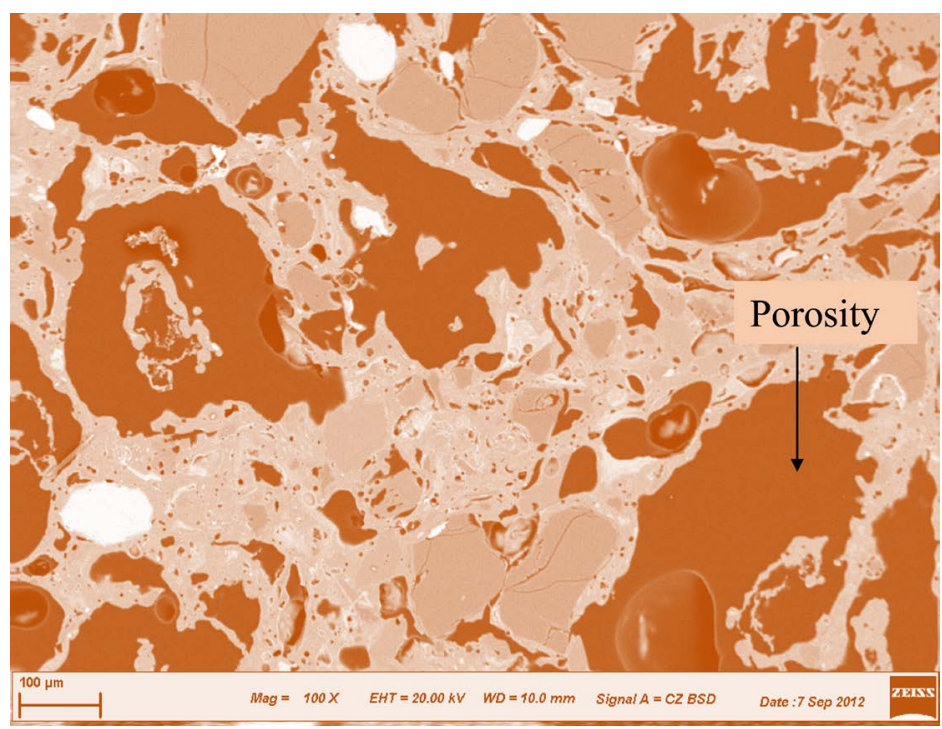

Figure 19. Sample 5OCZT4 at $1150^{\circ} \mathrm{C}$.

agro-waste is highly carbonaceous material.

The values of the physical, mechanical and thermal properties of the developed insulating refractory bricks from selected Nigeria fireclays and agro-waste compared favourably with ASTM standard specifications.

An enhanced insulating property can be obtained from any of the selected clays with $25 \mathrm{wt} \%$ - $30 \mathrm{wt} \%$ of coconut shell.

\section{References}

[1] Titiladunayo, I.F. and Fapetu, O.P. (2011) Selection of Clay for Furnace Lining in a Pyrolysis Process. Journal of Emerging Trends in Engineering and Applied Sciences (JETEAS), 2, 938-945.

[2] Esezobor, D.E., Obidiegwu, E.O. and Lawal, G.I. (2014) The Influence of Agro-Forestry Waste Additive on Thermal Insulating Properties of Refractory Bricks from Osiele Clay. Journal of Emerging Trends in Engineering and Applied Sciences (JETEAS), 5, 305-311.

[3] Olasupo, O.A. and Borode, J.O. (2009) Development of Insulating Refractory Ramming Mass from Some Nigerian Refractory Raw Materials. Journal of Minerals \& Materials Characterization \& Engineering (JMMCE) USA, 8, 667678.

[4] Jock, A.A., Ayeni, F.A., Jongs, L.S. and Kangpe, N.S. (2013) Development of Refractory Bricks from Nigerian Nafuta Clay Deposit. International Journal of Materials, Methods and Technologies, 1, 189-195.

[5] Aniyi, J.A. and Adewara, J.O.T. (1986) Refractory Properties of Kankara Clay. Proceedings of Annual Conference Nigeria Metallurgical Society, 14-19.

[6] Jonker, A. (2006) Insulating Refractory Materials from Inorganic Wastes Resources. Ph.D. Thesis, Department of Chemistry, Tshwane University of Technology, Pretoria, 11-47.

[7] Chesti, A.R. (1986) Refractories Manufacturing, Properties and Applications. Prentice Hall, New Delhi.

[8] Nwoye, C.I., Obidiegwu, E.O. and Nwankwo, N.E. (2011) Model for Computational Analysis and Predictive Assessment of Bulk Density of Fired Bricks Based on Incurred Shrinkage. Journal of Innovative Research in Engineering and Science, 2, 74-82.

[9] Aramide, F.O. (2012) Production and Characterisation of Porous Insulating Fired Bricks from Ifon Clay. Journal of Minerals and Materials Characterization and Engineering (JMMCE) USA, 11, 970-975. http://dx.doi.org/10.4236/jmmce.2012.1110097

[10] Simeon, I. and Oluwaseun, A. (2014) Adaptation of Odolewu Clay for Use as Refractory Material. International Journal of Scientific \& Engineering Research, 5, 837-843.

[11] Lawal, G.I., Amuda, M.O.H., Ifekoya, D.I., Kuforiji, C.U. and Olokode, O.S. (2008) Characterisation of the Refractory Properties of Osiele Clay. NSE Technical Transaction, 43, 21-32. 